\title{
Modelling the Impact of Responsibility Levels on Corporate Financial Performance: The Case of Top 100 Firms in Mauritius
}

\author{
Karishma Ansaram \\ Faculty of Law and Management, University of Mauritius \\ Reduit, Moka, Mauritius \\ Tel: 230-5920-0043Ｅ-mail: karishma.ansaram9@gmail.com \\ Neeveditah Pariag-Maraye \\ Faculty of Law and Management, University of Mauritius \\ Reduit, Moka, Mauritius \\ E-mail: n.pariag@uom.ac.mu
}

Received: June 26, 2018 Accepted: July 10, 2018 Published: August 4, 2018

doi:10.5296/ber.v8i3.13468ＵRL: https://doi.org/10.5296/ber.v8i3.13468

\begin{abstract}
The objective of this paper is to investigate the relationship between Corporate Social Responsibility (CSR) levels and the financial performance of Top 100 firms in Mauritius post the implementation of the mandatory CSR levy in 2009. Both qualitative and quantitative assessment of disclosures in the annual reports of the top 100 companies for the period 2010-2014. A CSR index based on Carroll's (1979) CSR pyramid was constructed which was used to rate their CSR disclosure levels as per the five dimensions; economic, legal, ethical, environmental and social responsibility. The scores computed were then regressed against the profitability levels to depict any correlation between the variables. The study revealed mixed results for the responsibility levels and financial performance. A positive relationship was noted in case of economic responsibility, negative relationship for legal and ethical responsibility while the social, environmental and responsibility levels generated an insignificant relationship with the profitability level of the top 100 firms.
\end{abstract}

Keywords: CSR, Environmental, Economic, Ethical, Legal, Social, Financial performance 


\section{Introduction}

The last 20 years has witnessed a metamorphosis in the way that businesses in emerging economies have moved away from conventional reporting to a more holistic triple bottom line approach (Samy, Halabi, Khan, 2009). Several studies have investigated the voluntary social reporting practices of businesses in developing countries (Soobaroyen, 2008; Ojo, 2015; Gokulsing, 2011) ranging from CSR impact on factors like human rights and employees' behavior to the impact on the economy as a whole. Soelen (2015) studied the impact of CSR on risk while Ojo (2015) analysed its relationship with FDI. Other studies by Jamali (2015) investigated CSR activities by SMEs and Guiliani (2014) the relationship between CSR and human rights advocacy. In a similar vein, extant scholarship has also examined the relationship between CSR reporting and financial performance in diverse emerging countries like Bangladesh, Malaysia, Sri Lanka and others (see, for example, Aras et al. 2010; Khasharmeh \& Suwaidan, 2010; Islam \& Deegan, 2008; and Ratanajoinkol et al., 2006).

In Mauritius, the CSR law was established in 2009 whereby profitable companies have to contribute $2 \%$ of their profit to social and environmental activities. This emerging practice has also given firms the opportunity to be more responsible and hence more accountable to different stakeholders. In this respect, Mahadeo, Oogarah-Hanuman and Soobaroyen (2011) has used content analysis to measure CSR reporting levels of listed companies and their motivations for such disclosures, Ntim and Soobaroyen, 2013; Khan, 2010 assessed the determinants of CSR disclosures and Soobaroyen and Mahadeo 2016 studied the changes in community disclosures. Extant literature on the CSR context in Mauritius has primarily focused on the CSR disclosures. This paper puts forward an assessment of the impact of the CSR level on the financial performance of the top 100 firms in Mauritius 5 years post the enactment of the CSR levy. The objective of this study is to assess how the reporting and hence the corporate social disclosures affect the financial performance of those companies compelled to carry out CSR. The use of qualitative data from the financial statements, director's report, corporate governance report and CSR report have been utilized for the purpose of this research. The following research question entails from the above. 'Investigating the CSR dimensions impact on the financial performance (thereafter FP) of the Top 100 companies in Mauritius'.

This paper addresses an introduction showing the importance of this topic and the problem in the area of study, literature review against which this paper is anchored, methodology adopted, data analysis, discussion and conclusion.

\section{Literature Review}

Over the past few decades, there has been increasing societal pressures for businesses for greater transparency and accountability. In order to legitimize their corporate behavior and meet stakeholders's demands, there has been a movement away from traditional corporate reporting of to that of a more inclusive triple bottom approach (Soelen,2015; Ojo,2015; Giuliani, 2014; Ramdhony \& Oogarah, 2012; Gokulsing, 2011; Soobaroyen, 2011; Islam \& Deegan,2008 and Gao\& Zhang, 2006). Several theories have been developed by Visser 
(2008), Elkington (1997) and Carroll (1991) to highlight the drivers of CSR reporting by companies. Visser (2011) identified the drivers of CSR in emerging economies to be principles of value creation, good governance, societal contribution and environmental integrity. The principle value creation refers to economic development in the form of investments in capital (financial, social, human and natural), sustainable and responsible goods and services and inclusive business activities like the emphasis on bottom of the pyramid markets. The principle good governance refers to responsible activities in the form of leadership or strategic commitment to sustainability, transparency and ethical business practices like the prevention of bribes and corruption.

\subsection{Dimensions of Corporate Reporting Practices}

Economic Responsibility: The economic responsibility of businesses is to report primarily to its shareholders as supported by the Milton Friedman Theory (1970). The firms should disclose information that will help to maximize their shareholder value by acting within laws and with their mission to bring along a long term competitive advantage. The economic responsibility to report reflects the need for financial reporting to shareholders. Firms make use of IASB framework to report their financial statements.

Legal Responsibility: Firms have the obligation to report as they are required to do so by laws and regulations (Aguilera, Rupp, Williams, \& Ganapathi, (2007). The stance for law and regulations is present due to the profit maximizing behavior of businesses and thereby violating laws to enhance their own interests, thus the government or international organizations need to intervene to manage corporate behavior (Hess (2010) \& Yam (2011). The Government is seen as the main driver for firms to carry out their legal responsibility.

Ethical Responsibility: Businesses as a corporate citizen should take the right decisions that will contribute towards the enhancement of the society (Garriga, (2004). Svensson and Wood (2009) have found that Ethical behavior is an ever-changing process according to time and culture. They further classified ethical behavior of managers in terms of Deontological (right or wrong) and Teological (impact on others). Business ethics is often related to the Board and Management as they are the ones responsible for good practice in the organization. This thereby gives rise to the concept of Corporate Governance. Corporate Governance is the way a company is directed and controlled. The Board is responsible for implementing proper standard behaviors and is accountable to the stakeholders. The Board has to abide by IASB principles while being accountable to their shareholder, that's why they have an audit committee, remuneration committee and all necessary disclosures.

Social Responsibility: The social Responsibility also emanates from the Social Contract Theory which was developed to assist managers in decision making with the social expectation in mind (Donaldson and Dunfee 1999). Sethi (1975) defined this dimension on a three states schema based on: (1) social obligations, (2) social responsibility and (3) social responsiveness. Davis (1960) stated that any organization has power and thus has an impact on the society but if it isn't responsible, it loses this power. The social responsibility can include Community Economic Development, a process through which firms can connect with the local communities to bring value added in terms of skills, education, health, housing and 
the environment (Centre for Community Enterprise 2008). This also gives rise to Business-NGO partnerships. ISO 26000 published in 2010, is not regarded as a certification standard as no requirement is included. It offers guidance on socially responsible behavior and possible actions and will only be used voluntarily to guide corporate social performance (ISO 2009).

Environmental Responsibility: Another dimension of the Triple Bottom line theory was the environment responsibility of businesses. Corporate activities have an impact on the environment and the repercussions usually tend to be adverse in the form of pollution, wastes, carbon emission and bio diversity. For this reason, it is important the businesses become more conscious of their environmental responsibility. It is also a win-win game as having more efficient input with less pollution and wastes results as less costs being incurred (Udin,Riad \& Kazi,(2008). Sustainability efforts are based on a single principle: to minimize the environmental footprint of a corporation's operations and maximize sustainability. The emerging practice in recent years has been the introduction of the ISO 14000 standard. It has a three-section environmental management system which covers initial planning, implementation and objective assessment.

\subsection{Research studies on CSR reporting in Mauritius}

Existing literature investigating the CSR disclosures of businesses in Mauritius has focused on different streamlines such as the motivations for CSR reporting, how the disclosures have changed over time or what are the views of stakeholders on CSR disclosure and activities.Gokulsing (2011)examined the rationale behind CSR activities in Mauritius and also how the programmes were contributing to the business objectives. The latter conducted interviews of different stakeholders to capture their views on CSR activities. Mahadeo, Soobaroyen and Oogarah (2011) studied the social and environmental disclosures of listed companies for the period 2004-2007 prior to the enactment of the law. They found a significant increase in volume and quality of disclosures in annual reports. Ramdhony and Oogarah (2012) investigated the motivations for CSR reporting by Mauritian companies and also proposed solutions to improve their reporting. They found out that the principle driver of CSR reporting is reputation management followed by compliance with the code of Corporate Governance. A more recent study by Soobaroyen and Mahadeo (2016) investigated changes in community disclosures of listed companies for a time period 2004-2010 and found that the disclosures were not due to international pressures but rather due to local tensions and expectations. Ramdhony ,Padachi and Giroffle (2010) examined the perspectives on Sustainability reporting and found that on company's behalf there are major obstacles such as time, reporting costs and measuring instruments of environmental activities. Ramdhony (2011) examined corporate reporting of local banks in Mauritius and found that bank with more visibility provide more CSR information which is in conformity with legitimacy theory. While the aforementioned research have primarily focused on the corporate social disclosures but from different perspectives and time span. First, we have extended the period of analysis post the implementation of the CSR levy in Mauritius to gauge the its impact on the level of disclosures categorized according to the five CSR dimensions and also on the performance of businesses. 


\section{MInstitute ${ }^{\text {Mach }}$}

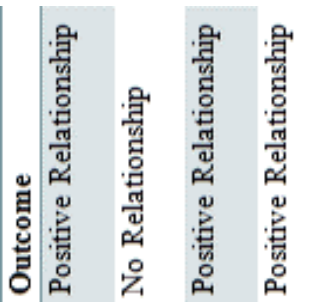

䄈 喜
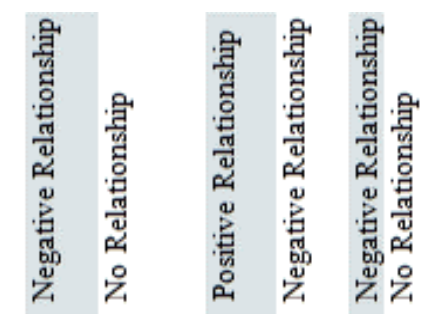

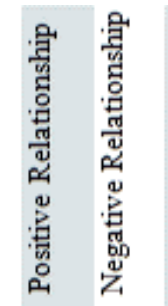

2018, Vol. 8, No. 3

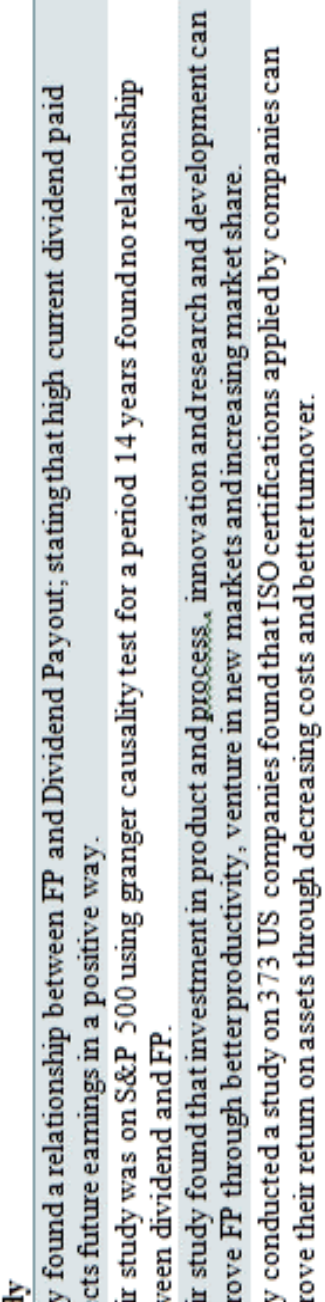

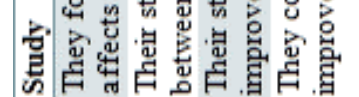

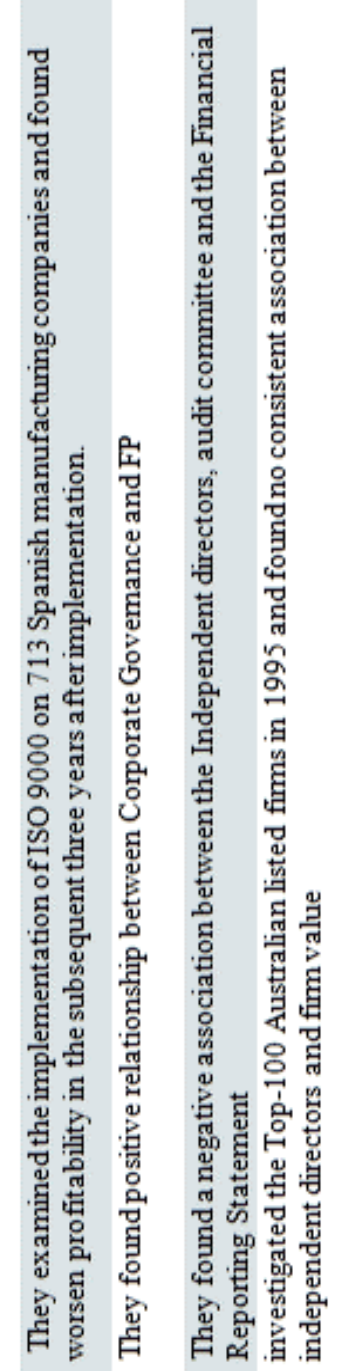

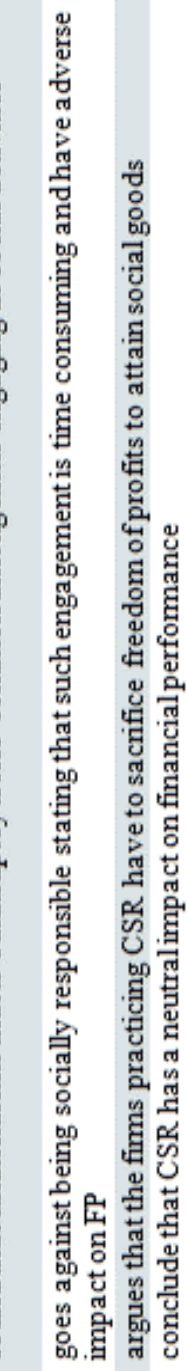

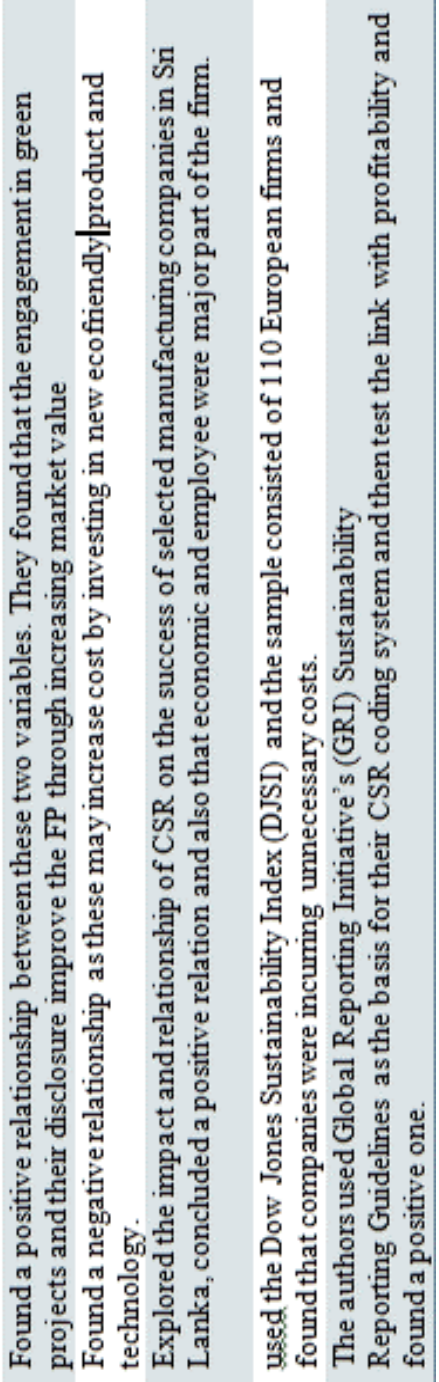

\section{:}

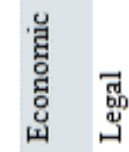

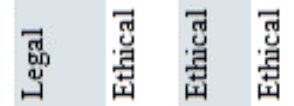

तु हु

तुํํ류
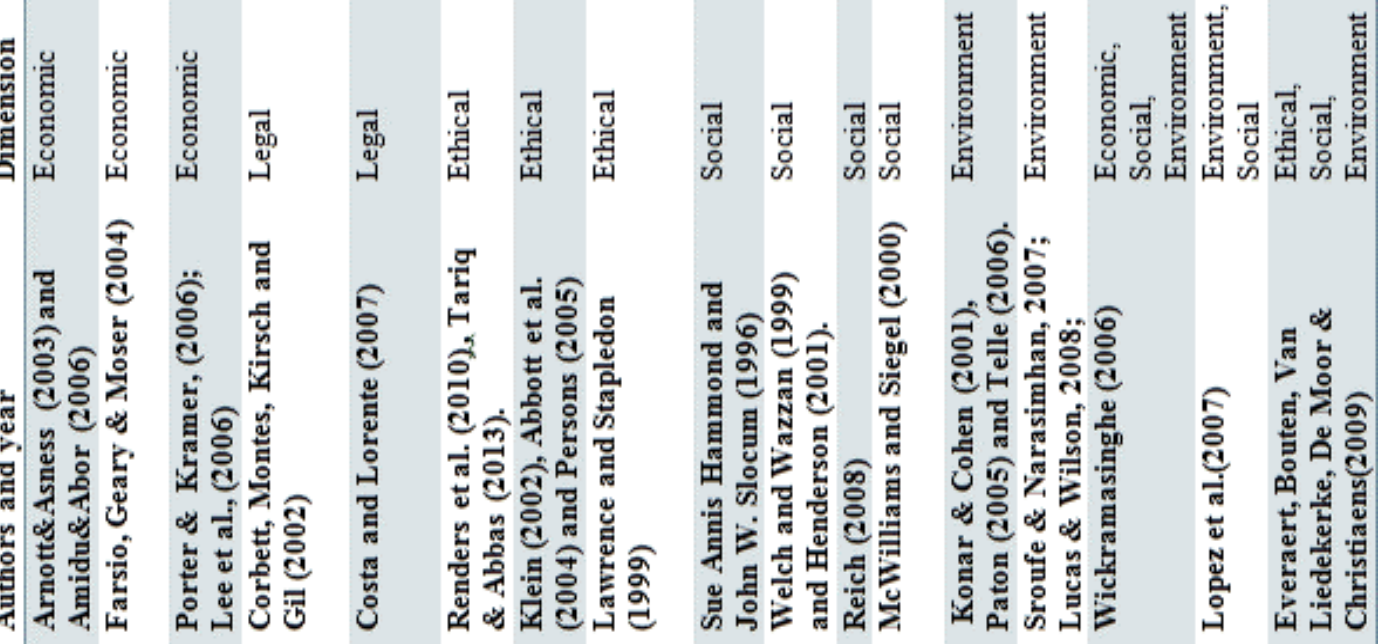


\subsection{Mauritian CSR Law}

The CSR levy transcends from a research conducted by Deloitte in 2008 to assess the CSR practices amongst Top 100 Companies 2006, SMEs and multinational firms. The motive of this research was to reinforce the NGO sector. The research found that the philanthropic tradition was prevalent in local firms and they also engaged in CSR activities since the last two decades. Furthermore, the report highlighted that although CSR practice dates back atleast 20 years, only 22 percent of businesses have a formal CSR policy.

The new mandatory CSR levy was enacted on $1^{\text {st }}$ July 2009 stipulating that all profitable registered businesses should contribute $2 \%$ of their annual book profits to CSR activities. Though prior to this new legislation, Mauritian companies were already engaged in CSR activities and were also reporting on a voluntary basis. The code of corporate governance issued in 2004 required all companies to comply with the regulation to report on policies and practices in relation to social, ethical, safety, health and environmental issues (NCCG). Thus, with the new CSR law, the companies have a legal obligation to maintain a CSR fund that contributes to social and environmental development of the country. The NCSR has published a list of approved programmes that qualify for financing through a CSR Fund. According to Income Tax section 2 (50L), A company shall submit as an annex to its return of income a statement showing the amount of CSR spent and the details of CSR projects implemented by the company.

The amount to be contributed is calculated as follows:

$$
\underset{* n 100}{2 *} \underline{b}
$$

where ' $b$ ' is the book profit derived by the company in the year forming the basis for the year of assessment ending on 30 June 2010.

Note: Book profit means the profit computed in accordance with International Financial Reporting Standards, after Income Tax and as reduced (increased) by profit(loss) on disposal or revaluation of fixed assets.

' n'is the number of months starting on 1 July 2009 to the end of the accounting year of the company forming the basis for the year of assessment ending 31December 2010.

\subsubsection{Environmental and Social Background in Mauritius}

Mauritius, being the paradise island for tourist attraction is not lagging behind to preserve its nature and to curb the problems of climate change, extreme weather events, ozone depletion, energy crisis, exhausted natural resources, pollution, loss of biodiversity, threat to food security and shrinking fish stocks.Established in 2000, the Police de l'Environnement provides assistance to the Director of Environment. From a social perspective, Mauritius has free education up to university level for all its citizens, free transportation for school children, the disabled and old aged persons, free health services and a free non- contributory old age pension for those above the age of sixty. There are also allowances to the widows, orphans, disabled, unemployed heads of low income households and destitute families with 
dependants. The National synthesis report for Rio Summit (2012), states that the Mauritian Government has been investing in its human capital over the years. In that respect Mauritius spends about $50 \%$ of its budget in comprehensive welfare system.

\section{Research Methodology}

This research uses content analysis to measure the responsibilities of firms as captured by the social and environmental disclosures.It is a technique most commonly used to quantify disclosures where no measure of responsibilities exists( Soobaroyen 2016; Dumay 2015 and Gao 2011). The annual reports of top 100 companies were used to carry out a content analysis (Unerman, 2000; Wolfe, 1991). There are two approaches to content analysis namely Vourvachis (2007); Index studies and volumetric studies. Index studies involve verify the presence or absence of certain information. In this research, the Index Studies has been used attributing a score of 1 if the information is present and otherwise a score of 0 . Furthermore, context studies have been applied which involves looking at the meaning of the word in the sentence, the whole paragraph or speech (Krippendorff, 2004).

\subsection{Data Collection}

For the purpose of this research the annual reports of the top 100 companies (list published by La Sentinelle Business Magazine Edition 2015) in Mauritius for the time period 2010 to 2014 were analysed. The top 100 companies were then classified across sectors to measure their respective responsibility levels. Although, companies provide various source of information like press, newsletters, standalone CSR reporting, website information, the annual reports remained the most reliable source of data (see Soobaroyen et al 2016; Soobaroyen 2013; Campbell, Moore, \& Shrives, 2006; and Islam \&Deegan, 2008).In Mauritius, the annual reports are publicly available with the registrar of companies and these reports can contain information both of voluntary and regulated type. Annual reports comprise of financial statements, corporate governance report and CSR disclosures. However, the governance code does not impede on companies to follow guidelines in reporting their social or environmental engagements. The only legal requirement regarding CSR is that companies must disclose the total amount of charitable donations.

The content analysis in this research has been executed in different stages.

1. First of all, a metrics of indices was constructed from existing global frameworks and other studies. This checklist had to be constructed since there is no organization to rate Mauritian companies on their responsibility levels.

2. The chairperson section, the corporate governance section, the auditor's responsibility statement, the financial statements and the CSR section were examined in the Annual reports. The next stage was to calculate the responsibility index.

3. In this study, the unweighted index approach is adopted (Haniffa and cook ,2002; Saleh et al, 2011 and ;Rouf, 2011)) to measure the disclosures as a dichotomous variable i.e if the companies disclose items as per the checklist, a score of 1 will be given or otherwise a score of 0 will be provided (Gujrati, 2009). 


\subsection{Regression Model}

Regression analysis was also used to depict any relationship between responsibility levels and the financial performance of the Top 100 companies for the period under consideration.A cross sectional data analysis was performed with financial performance as the dependent variable, each dimension of responsibility level as independent variable and company size, leverage and age as control variables. The regression model used is as follows:

$Y($ net profit before tax $)=\beta o+\beta 1$ Eco $+\beta 2$ Legal $+\beta 3$ Ethics $+\beta 4$ Social $+\beta 5$ Env + $\beta 60$ verall CSR $+\beta 7$ size $+\beta 8$ leverage $+\beta 9$ age $+\varepsilon$

$\beta o=$ intercept

Eco $=$ Economic Responsibility score

Legal= Legal Responsibility score

Ethics $=$ Ethical Responsibility score

Social=Social Responsibility score

Env= Environmental Responsibility score

\subsection{Hypotheses}

The hypotheses of this study are based on the relationship between responsibilities of a firm and its financial performance. Studies have shown that the relationship between social responsibilities and accounting-based performance measures is generally positive ( Yusuff \& Adamu, 2016; Kim \& Qian, 2015 ; Gbadamosi, 2014) .Contradicting this research, Mentor Marly (2016), Kruger (2015) and Mc Williams and Siegel (2012), offered a summary of previous conceptual explanations for negative, positive and no relationship between CSR reporting and financial performance.

H1: whether there is a relationship between economic responsibility and FP

H2: whether there is a relationship between legal responsibility and FP

H3: whether there is a relationship between ethical responsibility and FP

H4: whether there is a relationship between social responsibility and FP

H5: whether there is a relationship between environmental responsibility and FP

H6: whether there is relationship between responsibility level and FP

\subsection{Variables}

Financial Performance- profit before tax: Several studies have investigated the relationship between the CSR dimension and financial performance using profitability level (Ehsan and Kaleem,2012; Soana,2011; Dragomir 2010; Peters and Mullen 2009; McWIlliams and Siegel 2000).

Control Variables: This study introduces control variables that may influence the relationship 
between the responsibility of firms and their financial performance. This study will therefore use (1) company size, (2) leverage and (3) age of the firm as control variables. Company size is relevant as previous studies have shown that smaller companies may not have the same responsibility levels as the bigger ones. Waddock and Graves (1997) asserted that this may be due to growth of companies may attract more investoers thus implying more response to stakeholder needs. One of the company size measure is sales volume. A high volume of sales directly affects company profitability. The other factor of company size is total assets of the company. The present study utilizes these two factors for the company size as control variables. Leverage reflects the degree of financial risk a company is exposed to, and from a pragmatic legitimacy perspective, the company needs to manage perceptions of its closest stakeholders (lenders) to ensure its survival. Companies having a higher degree of risk are compelled to be more responsible to avert or delay a negative reaction by lenders (Haniffa \& Cooke,2005; Reverte,2009). Shreck (2011) states that there can be a relationship between responsibility level, financial performance and age of a firm. Peloza (2006) found that younger firms may want to improve financial performance rather than looking at all responsibility levels, only after doing well that they diversify their responsibility. Age is measured by the number of years since the firm has been established.

\section{Results}

As stated above, a panel data regression was carried out based on the OLS assumptions for stationary of data, heteroskedasticity test, normality test and chow breakpoint test.

\subsection{Descriptive Statistics}

Table 2. Descriptive Statistics

\begin{tabular}{|l|l|l|l|l|l|}
\hline Variable & Mean & Median & Max & Min & SD \\
\hline Economic & 2.528 & 3 & 5 & 0 & 1.35 \\
\hline Legal & 0.637 & 1 & 3 & 0 & 0.655 \\
\hline Ethical & 2.986 & 4 & 6 & 0 & 1.869 \\
\hline Social & 3.548 & 3 & 9 & 0 & 2.460 \\
\hline Environmental & 0.75 & 0 & 4 & 0 & 1.032 \\
\hline Total CSR score & 10.5 & 0 & 25 & 0 & 11 \\
\hline
\end{tabular}

On a total score of 30 (appendix), the top 100 firms only had a maximum of 25 and the median was 0 . A zero median is a negative signal that half of the sample have not yet adopted CSR yet. The standard deviations for the responsibility levels are relatively small, thus the scores do not deviate a lot. For the economic responsibility, the median was 3 which is more than $50 \%$ of the total 5 scores for the component. It can be deduced that Mauritian Firms were concerned about shareholders though on a sustainable basis, through the content analysis, no Socially Responsible Investment Program was mentioned. The legal score was 5 as well and the median and mean registered are quite low at 1 and 0.637 respectively. Since the index contained more compliance to ISO standards, this shows that local firms have still not adopt such international practices. The compliance to report on CSR and the auditing of same can be questioned since a zero score was found for the index. For ethical responsibility, 
the score was on 7 and the mean and median generated are 2.986 and 4 respectively. The median is above average and thus it can be deduced that the level of ethical practice amongst local firm is prevalent. The social responsibility was marked on a score of 9. A low score was noted for the median at 3 . From the content analysis, this might be due to the lack of diversification in projects whereby firms tend to focus on only a handful of social activities over the years. In addition, most of the organisations didn't have a CSR foundation in place that could execute their activities properly and eventually carry out monitoring and evaluation. Finally, the environment responsibility was assessed on a score of 4 . This has unfortunately registered a very low mean and median at 0.75 and 0 respectively. The raises concerns over the extent to which green practices have been adopted around the island. Given that there are programs that have been set, the organisations have still not approached these. These programs are not yet regulated, and this might be the result behind the slow rate towards green transition. From the responsibilities analysed, it can be deduced that economic and ethical dimensions were the most common one amongst firm in Mauritius.

\subsection{Regression Results}

Table 3. Correlation matrix for CSR dimensions and Financial Performance

\begin{tabular}{|l|l|l|l|l|l|l|l|}
\hline Correlation Matrix & Profit & CSR & ECO & LEGAL & ETHICAL & SOCIAL & ENV \\
\hline PROFIT & 1 & & & & & & \\
\hline CSR & 0.387313516 & 1 & & & & & \\
\hline ECO & 0.367143245 & 0.764992178 & 1 & & & & \\
\hline LEGAL & 0.269708668 & 0.6202532 & 0.451487 & 1 & & & \\
\hline ETHICAL & 0.279552857 & 0.851826456 & 0.555891 & 0.409657 & 1 & & \\
\hline SOCIAL & 0.341592727 & 0.897023552 & 0.587799 & 0.47949 & 0.680262 & 1 & \\
\hline ENV & 0.221777517 & 0.587722079 & 0.329202 & 0.403988 & 0.4005204 & 0.388902 & 1 \\
\hline
\end{tabular}

Table 4. shows the findings for CSR dimensions with Net Profit before Tax as dependent variable

\begin{tabular}{|l|l|l|l|l|l|}
\hline Dimension & Coefficient & P value & Outcome & Results & Type of relationship \\
\hline Economic & 1.9584 & 0.016343 & $\mathrm{P}<0.1$ & Relationship & Positive \\
\hline Legal & -2.8659009 & 0.0688932 & $\mathrm{P}<0.1$ & Relationship & negative \\
\hline Ethical & -1.8281028 & 0.0470659 & $\mathrm{P}<0.1$ & Relationship & Negative \\
\hline Social & -0.222620 & 0.761731 & $\mathrm{P}>0.1$ & No Relationship & \\
\hline Environmental & 0.167410 & 0.856019 & $\mathrm{P}>0.1$ & No relationship & \\
\hline Total CSR score & 1.60202 & 0.16277 & $\mathrm{P}>0.1$ & No relationship & \\
\hline
\end{tabular}

The study has generated a mix results of the corporate responsibilities and the correlation with their financial performance. A significant relationship was found among economic, legal and ethical responsibilities, however in case of social, environmental and overall CSR score the, insignificant relationships have been generated.

The economic responsibility has a 1.9584 correlation with the financial performance 
implying that each investment in economic responsibility tend to improve financial performance by 1.9584 units. As Milton Friedman (1970) stipulates, the first duty of a firm is to increase shareholder's wealth by being economically responsible. This view is also supported by Adam Smith, Danielson, Hutton et al, (1998) and Heck \& Shaffer (2008).

In the context of legal responsibilities, the top 100 companies have registered a significant negative relationship of -2.865 . Previous studies support the argument that adopting regulations can impact on FP in a positive manner, this was accredited by Corbett, Montes, Kirsch an\& Gil (2002), Chua, Goh and Wan (2002) who studied 146 firms in the Singaporean Market over a period of ten years. Our results tend to contradict literature by having a negative relationship for companies in Mauritius.

The top 100 companies have registered a negative correlation for the ethical responsibility and financial performance with a coefficient of -1.828 , implying that each unit of increase in ethical behavior will worsen FP by 1.828 units. The result is line with studies by Klein (2002), Abbott et al. (2004) and Persons (2005) whereby a negative association between ethics and FP was derived, that is when firms engages in Board, appoint Independent Directors, audit committee they have a worse FP.

The Top 100 companies also had an insignificant $\mathrm{P}$ value and thus revealing that companies in Mauritius FP decreases with social responsibility. Studies by Kang et al. (2010) and O’Neill, Saunders \& Derwinski McCarthy (1989) showed no relationship between these two variables while one study by Lopez et al. (2007) on European firms pointed out that social responsibility is just additional cost to the company. However, the study was on a short-term basis. Same applies for the study, which covered only five years; had the study been on a longer time period, the results generated would have been more reliable.

For environmental responsibility, at 90 percent significance level, no relationship was found with financial performance. Studies by Salama (2005) also found that environmental concerns adopted by companies do not influence their performance.

At 90 percent level of significance, no relationship was found in the top 100 companies, thus we reject the hypothesis that there is a relationship between CSR reporting and financial performance. Previous literature also showed no relationship among CSR reporting and financial performance (Bird et al., 2007; Tsoutsoura, 2004; Kang, Lee and Huh, 2010; Waddock and Graves, 1997; Simpson and Kohers, 2002).

\subsection{Discussion on Corporate Responsibility levels and Financial Performance}

Economic Responsibility is considered as the first and prime responsibility of any business. A positive relationship was found among the Top 100 companies. A good economic climate indeed improves the profitability of businesses. Mauritius has been able to rank itself on $20^{\text {th }}$ place for the Global Innovation index; it reflects the commitment of firms to invest in research and development and to innovate in order to increase shareholders' wealth. The government plays a big role to drive the economic behavior of firms. Similarly, government incentives can encourage firms to cater more for the healthiness of their business. The new budget 2015-2016 has been looking forward towards new relations with airlines with the 
tourism and hotel sector. The textile industries are benefitting from freight rebate scheme to Africa. With the smart city scheme in the near future, the economic behavior of firms might be expected to improve so as to attract investors and also venture towards new opportunities through diversification.

The negative relationship for legal responsibility registered could be due to the weakness in the CSR law which according to section 50 in the Income Tax law that all companies should report its CSR activities. However, in many cases these reports were not elaborated in the different spheres that the company has invested in. A study by Lamport, Sanassee and Seetanah (2010) on ISO certifications of listed firms on stock exchange found that they have better performance from these regulations. Even over the years, the correlation between these two variables was not strong. The study shows that Mauritian firms are still lagging behind in terms of legal reporting and disclosure or to implement and adopt new regulations. Had the firms optimize their resources towards more legal behavior they could have gain benefits such as more investors' confidence, better image thereby leading to better performance. Local firms still have much opportunities from these regulations that they can exploit.

Ethical behavior is a vital part of any organization and with the Corporate Governance Act (2004) in Mauritius, firms have to abide by international standards in their financial reporting and also have proper committees in place. The negative relationship found in the study is in conformity with a study by Lamport, Latona, Seetanah and Sanassee (2011) who investigated the relationship of corporate governance among Top 100 firms Mauritius and found a worsening performance of local firms. In addition, their study conclude that the Corporate Governance Act will take time to be fully implemented by companies so that they are able to take the whole benefit. In the modern age, the moral dilemma of businesses is ever changing and on constant increase. Local firms should also consider their ethical conduct in their daily operations as ethics is not only linked with profitability but to stakeholders too.

The study also investigates the post CSR law implementation by companies. No relation was found amongst the social responsibility and FP for the period 2010-2014. This poor score might be due to recent implementation of the Act and firms have not been able to engage in many activities at the start. Also, the local firms need to have the appropriate CSR committee to be able to undertake efficient use of the fund. There was also only a sole platform whereby the companies could interact with NGOs. Recently, the Ciel Group Company has set up the ACT platform whereby NGOs can request funds from corporate. In the long run, local firms can become more socially responsible as NGOs for different causes are setting up and more online platforms are being created. Similarly, it can be expected that firms will reap the benefits of being socially responsible by generating higher profits in the long run.

Over the period of five years, companies did not demonstrate high rate of involvement in Environmental activities. One of the main reasons of this low score might be the barriers to environment reporting by Mauritian companies. It is difficult to assess environmental costs and its benefits objectively. Furthermore, as Ramdhony ,Padachi and Giroffle (2010) stated, there are major obstacles such as time, reporting costs and measuring instruments of environmental activities. Only a couple of companies were most likely to adopt the ISO 
14000 on Environment Management.Contribution to environment is among the area of investment in the CSR activities of the NEF. Due to recent implementation of the Act, it is only now that Mauritius is witnessing the creations of more NGOs to cater for the environment. The government has put in place several mechanisms to promote sustainability around the island. Even green financial products like the eco loan are available on the markets to allow consumers and firms to go towards green energy consumption. Mauritius also had the opportunity to have a solar farm established since 2012 which contributes to the electricity production too. Local firms need more experts in Environmental Accounting and Management so that proper reporting and assessment can be carried out. In the long term, it can be expected that firms investing in recycling and green products might see their costs decrease and also able to create a brand image.

This paper also concludes that there is no relationship between financial performance and corporate responsibility levels. The absence of a significant relationship between responsibility levels and financial performance has been reported by previous studies too (Bird et al., 2007; Tsoutsoura, 2004; Kang and Lee, 2010; Waddock and Graves, 1997; Simpson and Kohers, 2002; Waddock and Graves, 1997). Kang and Lee (2010) reported that too many events and factors may impact on financial performance to be able to have a relationship among the variables. Studies by Waddock and Graves (1997) stated that there is no reason to expect any relationship since there are several intervening variables. Similarly, there may be other factors that need to be analysed to be able to gauge the relationship between responsibility levels and financial performance. Post CSR levy in 2009, firms' financial performance has not been influenced for the five years 2010 to 2014 .

\section{Conclusion}

This study was based on assessing the responsibility levels of Top 100 companies in Mauritius. The study has found that firms having better responsibility level do not experience any changes in their FP. Though the Income Tax Act stipulates that companies should report their CSR activities, however reluctance was found on behalf of several companies especially the family own business which didn't do proper reporting. Visser (2008) driver's such as investment incentives, political reforms and cultural tradition can push the companies to adopt a more responsible reporting behavior. Mauritius aiming to be a pioneer in sustainability should put in place proper frameworks like the GRI to rate companies in their activities. Through this companies may be motivated to do proper reporting as they are well aware that they will be compared through ratings.

\section{References}

Abbott, W. F., \& Monsen R. J. (1979). On the measurement of corporate social responsibility: self-reported disclosures as a method of measuring corporate social involvement. Academy of Management Journal, 22, 501-515.

Aguilera, R. V., Rupp, D. E., Williams, C. A., \& Ganapathi, J. (2007). Putting the S back in Corporate social responsibility: a multilevel theory of social change in organizations. The Academy of Management Review, 32(3), 836-863. 
https://doi.org/10.5465/amr.2007.25275678

Aguinis, H., \& Glavas, A. (2012), What We Know and Don't Know About Corporate Social Responsibility: A Review and Research Agenda. Journal of Management, 38(4), 932-968. https://doi.org/10.1177/0149206311436079

Aras, G., Aybars, A., \& Kutlu, O. (2010). Managing Corporate Performance: Investigating the Relationship between Corporate Social Responsibility and Financial Performance in Emerging Markets. International Journal of Productivity and Performance Management, 59(3), 229-254. https://doi.org/10.1108/17410401011023573.

Aupperle, K. E., Carroll, A. B., \& Hatfield J. D. (1985). An empirical examination of the relationship between corporate social responsibility and profitability. Academy of Management Journal, 28, 446-463. https://doi.org/10.5465/256210

Bhattacharyya, A. (2016). Corporate Social and Environmental Responsibility in an Emerging Economy: Through the Lens of Legitimacy Theory. Australasian Accounting, Business and Finance Journal, 9(2), 79-92

Bragdon, J., \& Marlin, J. A. (1972). Is pollution profitable? Risk Management, 19, 9-18.

Branco, M. C., \& Rodrigues, L. L. (2006), Corporate social responsibility and resource based Perspectives. Journal of Business Ethics, 69(2), 111-132.

https://doi.org/10.1007/s10551-006-9071-z

Campbell, D., Moore, J., \& Shrives, P., (2006). Cross - sectional effects in community disclosure. Accounting, Auditing \& Accountability Journal, 19(1), 96-114.

https://doi.org/10.1108/09513570610651966

Carroll, A. B. (1991). The pyramid of corporate social responsibility: toward the moral management of organizational stakeholders. Business Horizons 34(4), 39-48.

https://doi.org/10.1016/0007-6813(91)90005-G

Chua, C. C, Goh, M., \& Wan, T. B. (2003). Does ISO 9000 Certification improve business performance?. International Journal of Quality and Reliability Management, 20(8), 936-953.

Corbett, C., Montes-Sancho, M., \& Kirsch, D. (2005). The Financial Impact of ISO 9000 certification in the United States. Management Science, 51(7), 1046-1059.

Davis, K. (1960). Can business afford to ignore social responsibilities?. California Management Review, 2, 70-76. https://doi.org/10.2307/41166246

Donaldson, T., \& Dunfee, T. W. (1999). Ties That Bind: A Social Contracts Approach to Business Ethics. Boston, MA: Harvard Business School.

Dragomir, V. D. (2010). Environmentally sensitive disclosures and Financial performance in European setting. Journal of Accounting and Organisational Change, 6, 359-388.

https://doi.org/10.1108/18325911011075222

Dumay, J. (2015). New frontiers in the use of intellectual capital in the public sector. Journal 
of Intellectual Capital, 16(2), 258-266. https://doi.org/10.1108/JIC-02-2015-0017

Ehsan, S., \& Kaleem, D. A. (2012). An empirical investigation of relationship between corporate social responsibility and financial performance: evidence from manufacturing sector of Pakistan. Journal of Basic and Applied Scientific Research, 2(3), 2909-2922.

Elkington, J. (1997). Cannibals with forks: The triple bottom line of 21st century business. Capstone, Oxford.

Friedman. M. (1970). The Social Responsibility of Business is to Increase its Profits. The New York Times Magazine.

Gao, S., \& Zhang, J. (2006). Stakeholder engagement, social auditing and corporate sustainability. Business Process Management Journal, 12(6), 722-740.

https://doi.org/10.1108/14637150610710891

Garriga, E., \& Melé., D. (2004). Corporate social responsibility theories: Mapping the territory. Journal of Business Ethics, 53(1-2), 51-71.

https://doi.org/10.1108/14637150610710891

Gokulsing, R. D. (2011). CSR in the context of globalization in Mauritius. Governance in the Business Environment (Developments in Corporate Governance and Responsibility, 2, 153-175. https://doi.org/10.1108/S2043-0523(2011)0000002011

Griffin, J. J., \& Mahon, J. F. (1997). The corporate social performance and corporate financial performance debate. Business \& Society. https://doi.org/10.1177/000765039703600102

Güler, A., Asl1, A., \& Ozlem, K. (2010). Managing corporate performance: Investigating the relationship between corporate social responsibility and financial performance in emerging markets. International Journal of Productivity and Performance Management, 59(3), 229-254.

Hackston, D., \& Milne, M. J. (1996).Some Determinants of Social and Environmental Disclosures in New Zealand Companies. Accounting, Auditing and Accountability Journal, 9(1), 77-108. https://doi.org/10.1108/09513579610109987

Haniffa, R. M., \& Cooke, T. E. (2002).Culture, Corporate Governance and disclosure in Malaysian Corporations. Abacus, 38(3). https://doi.org/10.1111/1467-6281.00112

Hess, J. (2010). Ethical brand management: customer relationships and ethical duties". Journal of pro-duct \& brand management, 240-249.

https://doi.org/10.1108/10610421011059568

Holsti, O. R. (1969). Content Analysis for the Social Sciences and Humanities. AddisonWesley Publishing Company, Reading, MA. Zenship, 17. 30-32.

Islam, M. A., \& Deegan, C. (2008). Motivations for an organization within a developing country to report social responsibility information. Accounting and Auditing Journal, 21(6), 850-874. https://doi.org/10.1108/09513570810893272 


\section{Macrothink}

Business and Economic Research ISSN 2162-4860 2018, Vol. 8, No. 3

Ismail \& Haddow. (2014). The impact of the theory of legitimacy on the disclosure of organizations in Jordan using a linear regression model. European Journal of Business and Management, 6(16).

Khan. (2009). Corporate social responsibility (CSR) reporting: a study of selected banking companies in Bangladesh. Social Responsibility Journal, 5(3), 344-357.

https://doi.org/10.1108/17471110910977276

Khan, (2010). The effect of corporate governance elements on corporate social responsibility (CSR) reporting: Empirical evidence from private commercial banks of Bangladesh. International Journal of Law and Management, 52(2), 82-109.

https://doi.org/10.1108/17542431011029406

Khasharmeh, H., \& Suwaidan, M. S. (2010). Social responsibility disclosure in corporate annual reports: evidence from the Gulf Cooperation Council countries. International Journal of Accounting, Auditing and PerformanceEvaluation, 6(4), 327-345.

https://doi.org/10.1504/IJAAPE.2010.036150

Klein, A. (2002). Audit committee, board of director characteristics, and earnings management. Journal of Accounting \& Economics, 33, 375-400.

Krippendorff, K. (2004).Content analysis, an introduction to its methodology. Sage Publications Inc., Thousand Oaks, CA.

Jamali et al. (2015). Near and dear? The role of location in CSR engagement. Strategic Management Journal.

Lamport, M., Seetanah, B., Conhyedass, P., \& Sannassee, R. V. (2010). The association between ISO 9000 certification and financial performance. International Research Symposium in Service Management.

Lin, C., Yang, H., \& Liou, D. (2009). The impact of corporate social responsibility on financial performance: Evidence from business in Taiwan. Technology in Society, 31(1), 56-63. https://doi.org/10.1016/j.techsoc.2008.10.004

Lopez, V. M., Garcia, A., \& Rodriguez, L. (2007). Sustainable development and corporate performance: A study based on the Dow Jones Sustainability Index. Journal of Business Ethics, 75, 285-300.

Lynes, M. (2008). Motivations for corporate social and environmental responsibility: A case study of Scandinavian Airlines. Journal of International Management, 14(4), 377. https://doi.org/10.1016/j.intman.2007.09.004

Mahadeo, J. D., Oogarah-Hanuman, V., \& Soobaroyen, T. (2011). Changes in social and environmental reporting practices in an emerging economy (2004-2007): Exploring the relevance of stakeholder and legitimacy theories .Accounting Forum, 35(3), 158-175

McGuire, J. B., Sundgren, A., \& Schneeeweis, T. (1988). Corporate social responsibility and firm financial performance. Academy of Management Journal, 31, 854-872. 
McIntosh, M., Leipziger, D., Jones, K., \& Coleman, J. (1998). Corporate Citizenship: Successful Strategies for Responsible Companies. London: Pitman

McWilliams, A., \& Siegel, D. (2000). Corporate social responsibility and financial performance: Correlation of misspecification? Strategic Management Journal, 21, 603-609. https://doi.org/10.1002/(SICI)1097-0266(200005)21:5<603::AID-SMJ101>3.0.CO;2-3

Mentor, M. (2016). The Effects of Corporate Social Responsibility on Financial Performance. Honors in the Major Theses.

Milne, M. J., \& Adler, R. W. (1999). Exploring the reliability of social and environmental disclosures content analysis. Accounting \& Auditing Journal, 12(2), 237-256.

https://doi.org/10.1108/09513579910270138

Morsing, M., \& Schultz, M. (2006). Corporate social responsibility communication: stakeholder information, response and involvement strategies. Business Ethics: A European Review, 15(4), 323-338. https://doi.org/10.1111/j.1467-8608.2006.00460.x

Moussa, G., \& Haasan, T. (2015). Legitimacy Theory and Environmental Practices:Short Notes. International Journal of Business and Statistical Analysis.

Ntim, C., \& Soobaroyen, T. (2013). Corporate Governance and Performance in Socially Responsible Corporations: New Empirical Insights from a Neo - Institutional Framework. Wiley online library. Corporate Social Responsibility, 21(5), 468-494.

Ojo, M. (2015). Poverty Reduction in Developed and Developing Countries: Analyzing the Relationship between Corporate Social Responsibility and Foreign Direct Investment. IGI Global, Forthcoming.

Orlitzky, M., Schmidt, F., \& Rynes, S. (2003). Corporate social and financial performance: A meta-analysis. Organization Studies, 24, 403-441.

https://doi.org/10.1177/0170840603024003910

Palmer, H. J. (2012). Corporate Social Responsibility and Financial Performance: Does it Pay to Be Good? CMC SeniorTheses. Paper 529.

Peloza, J. (2009). The Challenge of Measuring Financial Impacts From Investments in Corporate Social Performance. Journal of Management, 35(6), 1518-1541.

https://doi.org/10.1177/0149206309335188

Peloza J. (2011). The Challenge of Measuring Financial Impacts From Investments in Corporate Social Performance. Journal of Management, School of Business Administration, Simon Fraser University, Burnaby, British Columbia, Canada

Porter \& Kramer. (2006). Strategy and Society: the link between competitive advantage and corporate social responsibility. Harvard Business Review, 84(12), 78-92

Ramdhony, D., \& Oogarah (2012). Improving CSR Reporting in Mauritius - Accountants' perspectives. World Journal of Social Sciences, 2(4), 195-207. 
Ramdhony, D., Padachi, K., \& Giroffle, L. (2010). Environmental Reporting in Mauritian Listed Companies. International Research Symposium in Service Management.

Rashid, A., Lodh, S., \& Rudhkin, K. (2010). Board composition and firm performance: evidence from Bangladesh. Australasian Accounting Business \& Finance Journal, 4(1), 76-95.

Ratanajoinkol, S., Davey, H., \& Low, M. (2006). Corporate social reporting in Thailand, the news is all good and increasing. Qualitative Research in Accounting \& Management, 3(1), 67. https://doi.org/10.1108/11766090610659751

Reverte, C. (2009). Determinants of corporate social responsibility disclosure ratings by Spanish listed firms. Journal of Business Ethics, 88(2), 351-366.

Rouf, M. A. (2011). The corporate social responsibility disclosure: a study of listed companies in Bangladesh. Business and Economics Research Journal, 2(3), 19-32

Salama et al. (2005). Quantity versus quality: the impact of environmental disclosures on the reputations of UK Plcs. The British Accounting Review, 37(2), 231-248

Saleh, M., Norhayah, Z., \& Rusnah, M. (2011). Looking for evidence of the relationship between corporate social responsibility and corporate financial performance in an emerging market. Asia Pacific Journal of business Administration, 3(2).

https://doi.org/10.1108/17574321111169849

Sethi, S. P. (1975). Dimensions of Corporate Social Performance: An analytic framework. California Management Review, 17, 58-64. https://doi.org/10.2307/41162149

Soobaroyen, T., \& Mahadeo, J. D. (2008). Selective compliance with the corporate governance code in Mauritius: Is legitimacy theory at work? Research in Accounting in Emerging Economies, 8, 239-272. https://doi.org/10.1016/S1479-3563(08)08009-2

Soobaroyen et al. (2011). Changes in social and environmental reporting practices in an emerging economy (2004-2007): Exploring the relevance of stakeholder and legitimacy theories. Elsevier ltd

Soobaroyen, T., \& Mahadeo, J. D. (2016). Community disclosures in a developing country:insights from a neo-pluralist perspective. Accounting, Auditing \& Accountability Journal, 29. https://doi.org/10.1108/AAAJ-08-2014-1810

Sun, L. (2012). Further evidence on the association between corporate social responsibility and financial performance. International Journal of Law and Management, 54(6). https://doi.org/10.1108/17542431211281954

Surroca, J., Tribó, J. A., \& Waddock, S. (2009). Corporate responsibility and financial performance: the role of intangible resources. Strategic Management Journal, 31(3), 463-490. https://doi.org/10.1002/smj.820

Svensson, G., \& Wood, G. (2009). Business Ethics: through time and across contexts. StudentlitteraturAB. 1 . 


\section{Macrothink}

Tsang, E. W. K. (1998). A longitudinal study of corporate social reporting in Singapore: the case of banking, food and beverages and hotel industries. Accounting, Auditing \& Accountability Journal, 11(5), 624-635. https://doi.org/10.1108/09513579810239873

Uddin, B., Hassan, M., \& Kazi, M. (2008). Three dimensional aspects of Corporate Social Responsibility. Daffodil International University, Journal of Business and Economics.

Unerman, J. (2000). Methodological issues - Reflections on quantification in corporate social reporting content analysis. Accounting, Auditing \& Accountability Journal, 13(5), 667-681, https://doi.org/10.1108/09513570010353756

Visser, W. (2005). Revisiting Carroll's CSR pyramid: An African perspective. In $M$. Huniche\& E. R. Pedersen (Eds.), Corporate citizenship in developing countries: New partnership perspectives, Copenhagen: Copenhagen Business School Press, 29-56

Visser, W. (2008). Corporate Social Responsibility in Developing Countries. In A. Crane, A. McWilliams, D. Matten, J. Moon \& D. Siegel (eds.), The Oxford Handbook of Corporate Social Responsibility, Oxford: Oxford University Press, 473-479.

Visser, W. (2011). The Ages and Stages of CSR: Towards the Future with CSR 2.0, CSR International Paper Series, No. 3. First published in Social Space 2011.

Vourvachis. (2007). On the Use of Content Analysis (CA) in Corporate Social Reporting (CSR): Revisiting the debate on the units of analysis and the ways to define them. Department of Accounting \& Finance Kingston University Kingston Hill, Surrey.

Waddock, S. A., \& Graves, S. B. (2000). Performance characteristics of social and traditional investments. Journal of Investing, 9, 27-38. https://doi.org/10.3905/joi.2000.319421

Yam, S. (2011). The practice of corporate social responsibility by Malaysian developers. Property Management, 31(1), 76-91.

https://doi.org/10.1108/02637471311295423 
Appendix 1: Index Constructed

\begin{tabular}{|c|c|c|}
\hline Objectives & Indices & $\begin{array}{l}\text { Supporting } \\
\text { Literatures/Frameworks }\end{array}$ \\
\hline \multicolumn{3}{|c|}{ Economic Responsibility (5 scores) } \\
\hline Maximizing Shareholder's Wealth & $\begin{array}{l}\text { 1. Evidence of Growth in Profit } \\
\text { 2. Payment to capital providers, } \\
\text { Dividend paid during the year }\end{array}$ & $\begin{array}{l}\text { Milton Friedman (1979), } \\
\text { GRI } 2011\end{array}$ \\
\hline $\begin{array}{l}\text { Demonstrated commitment to } \\
\text { work towards long-term business } \\
\text { sustainability }\end{array}$ & $\begin{array}{l}\text { 3. Risks and Crisis Management } \\
\text { System Implemented } \\
\text { 4. Investment in Research and } \\
\text { Development } \\
\text { 5. Goodwill/Brand of the firm }\end{array}$ & $\begin{array}{l}\text { Knoepfel (2001) Dow Jones Index, } \\
\text { FTSE Johannesburg SRI. Goldman } \\
\text { Sachs ESG (2006), Székely (2005) }\end{array}$ \\
\hline \multicolumn{3}{|c|}{ Legal Responsibility (5 scores) } \\
\hline $\begin{array}{l}\text { Public commitment to comply } \\
\text { with an internationally recognized } \\
\text { standard }\end{array}$ & $\begin{array}{l}\text { 6. ISO 22301:2012- Business } \\
\text { Continuity } \\
\text { 7. ISO 14000- Environmental } \\
\text { Management } \\
\text { 8. ISO 9001:2008- Human } \\
\text { Resource Guideline }\end{array}$ & ISO \\
\hline Compliance with local regulations & $\begin{array}{l}\text { 9. CSR Reporting in Annual } \\
\text { Reports }\end{array}$ & $\begin{array}{l}\text { Income Tax Act of Mauritius } \\
\text { Section } 50\end{array}$ \\
\hline Breach of Laws and Regulations & $\begin{array}{l}\text { 10. Whether any case of } \\
\text { noncompliance is mentioned in } \\
\text { Reports }\end{array}$ & FTSE Johannesburg SRI \\
\hline \multicolumn{3}{|c|}{ Ethical Responsibility (7 scores) } \\
\hline $\begin{array}{l}\text { Uphold and support good } \\
\text { corporate governance practices as } \\
\text { the foundation for its business } \\
\text { policies and practices, through } \\
\text { strategies to achieve and maintain } \\
\text { internationally recognized } \\
\text { corporate governance standards } \\
\text { and implementing sound ethical } \\
\text { practices }\end{array}$ & $\begin{array}{l}\text { 11. Proper Strategy for Whistle } \\
\text { blowing } \\
\text { 12. Corporate Governance- CEO } \\
\text { and Chairman Separation } \\
\text { 13. Audit Committee in place } \\
\text { 14. Remuneration Committee in } \\
\text { place } \\
\text { 15. Majority Non-Executive } \\
\text { Directors } \\
\text { 16. Codes of conduct and ethics } \\
\text { 17. Political Donation }\end{array}$ & $\begin{array}{l}\text { Prasad fall } 2008 \text { (Supply Chains } \\
\text { Systems) Goldman Sachs ESG } \\
\text { (2006) FTSE Johannesburg SRI. } \\
\text { IASB }\end{array}$ \\
\hline \multicolumn{3}{|c|}{ Social Responsibility (9 scores) } \\
\hline $\begin{array}{l}\text { Working to promote the health, } \\
\text { safety and security of its } \\
\text { employees and in society }\end{array}$ & $\begin{array}{l}\text { 18. Provision of Safety and } \\
\text { Equipmentes } \\
\text { 19. Health care to the society } \\
\text { 20. Contribution to employees } \\
\text { pension benefit }\end{array}$ & $\begin{array}{l}\text { Prasad fall (2008) (Supply Chains } \\
\text { Systems), Goldman Sachs ESG } \\
\text { (2006),ISO } 26000\end{array}$ \\
\hline
\end{tabular}




\section{MlMacrothink}

Business and Economic Research

ISSN 2162-4860

2018, Vol. 8, No. 3

\begin{tabular}{|c|c|c|}
\hline $\begin{array}{l}\text { Actively promoting the } \\
\text { development and empowerment } \\
\text { of its employees }\end{array}$ & $\begin{array}{l}\text { 21. Employment Creation Skill } \\
\text { and Development (training) } \\
\text { 5. Employee Volunteering } \\
\text { programs }\end{array}$ & ISO 26000 Bombardier Index \\
\hline $\begin{array}{l}\text { Demonstrated commitment to be } \\
\text { involved in community } \\
\text { development or upliftment }\end{array}$ & $\begin{array}{l}\text { 22. Program to Promote } \\
\text { Education } \\
\text { 23. Program to alleviate poverty } \\
\text { through provision of housing } \\
24 \text { or entrepreneurship } \\
\text { empowerment } \\
\text { 25. contribution to sports and } \\
\text { games }\end{array}$ & $\begin{array}{l}\text { V. L. Blackburn, M. Doran and C. } \\
\text { B. Shrader } 1994\end{array}$ \\
\hline \multicolumn{3}{|c|}{ Environment Responsibility (5 scores) } \\
\hline $\begin{array}{l}\text { Working to reduce and control its } \\
\text { direct negative environmental } \\
\text { impacts }\end{array}$ & $\begin{array}{l}\text { 26. Carbon Emission Reduction } \\
\text { Commitments } \\
\text { 27. Recycling programs }\end{array}$ & $\begin{array}{l}\text { V. L. Blackburn, M. Doran and C. } \\
\text { B. Shrader 1994, Goldman Sachs } \\
\text { ESG 2006, Prasad fall } 2008 \\
\text { (Supply Chains Systems), FTSE } \\
\text { Johannesburg SRI Index }\end{array}$ \\
\hline $\begin{array}{l}\text { Working to use natural resources } \\
\text { in a sustainable manner }\end{array}$ & $\begin{array}{l}\text { 28. Direct Energy Consumption } \\
\text { from Primary Source (solar /wind } \\
\text { energy) }\end{array}$ & GRI 2011 \\
\hline $\begin{array}{l}\text { Design products and } \\
\text { manufacturing processes to } \\
\text { minimize the ecological footprint } \\
\text { along the entire product life cycle }\end{array}$ & $\begin{array}{l}\text { 29. Eco Design Products or } \\
\text { Packaging }\end{array}$ & $\begin{array}{l}\text { Knoepfel } 2001 \text { Dow Jones Index, } \\
\text { GRI } 2011\end{array}$ \\
\hline $\begin{array}{l}\text { Strategies for Indirect Impact on } \\
\text { the Environment }\end{array}$ & $\begin{array}{l}\text { 30. Engaging in Activities to } \\
\text { protect Natural Environment and } \\
\text { wildlife }\end{array}$ & $\begin{array}{l}\text { Knoepfel } 2001 \text { Dow Jones Index, } \\
\text { GRI } 2011\end{array}$ \\
\hline \multicolumn{3}{|c|}{ Total CSR score $=30$} \\
\hline
\end{tabular}

\section{Copyright Disclaimer}

Copyright for this article is retained by the author(s), with first publication rights granted to the journal.

This is an open-access article distributed under the terms and conditions of the Creative Commons Attribution license (http://creativecommons.org/licenses/by/3.0/). 